\title{
Verkkoteknologian haasteita ja mahdollisuuksia aikuisopiskelussa
}

\author{
Sallila, P. \& Kalli, P. \\ (toim.) (2001) Verkot ja \\ teknologia aikuisopis- \\ kelun tukena. Aikuis- \\ kasvatuksen 42 . vuosi- \\ kirja. Kansanvalistus- \\ seura ja Aikuiskasva- \\ tuksen Tutkimusseura.
}

Kirja on yksi laajimmista ja monipuolisimmista verkkopohjaisia oppimisympäristöjä käsittelevistä suomenkielisistä teoksista. Lähtökohtana kirjan kirjoittamiselle on verkkopohjaisten oppimisympäristöjen suosion räjähdysmäinen kasvu. Luottamus viestintäteknologiaan on nykyään erittäin korkealla tasolla aikuiskoulutuksessa, ja verkon uskotaan syrjäyttävän huomattavassa määrin perinteisiä koulutusratkaisuja. Kirjan tavoitteena on tarkastella teoreettisten pohdintojen ja empiiristen esimerkkien avulla verkkoteknologian merkitystä ja mahdollisuuksia aikuiskoulutuksessa ja oppimisessa. Ennen kaikkea kirjassa pyritään kriittisyyteen. Teknologista muutosta ei lupaavista mahdollisuuksista huolimatta hyväksytä aikuiskoulutukseen itsestäänselvyytenä, vaan kirjoittajat haluavat tuoda esiin myös verkkoteknologian ongelmia ja rajoituksia.

\section{Kirjan 12 artikkelia} perustuvat viime aikojen uusimpiin tutkimuksiin ja käytännön kokemuksiin, ja ne ovat aikuiskoulutuksen ja verkko-opetuksen asiantuntijoiden kirjoittamia. Artikkeleissa lähestytään verkko-op- pimista monista eri lähtökohdista.

\section{Verkkopohjaisten}

oppimisympäristöjen haasteiden ja mahdollisuuksien kartoittaminen on yksi kirjan keskeisistä teemoista. Hakkaraisen mukaan verkkopohjaisten oppimisympäristöjen suurimpana ongelmana on nykyisin yhteisöllisyyden ja vuorovaikutuksellisuuden puute. Materiaalia siirretään verkkoon vanhan, tiedonsiirtoon perustuvan oppimiskäsityksen mukaisesti. Hakkaraisen vastaus yhteisöllisempään oppimiseen on tutkivan verkko-oppimisen malli, joka tähtää tiedonsiirron sijasta oppimiskulttuurin muutokseen. Teoreettisen mallin luomisen ohella voidaan kartoittaa myös verkkopohjaisten oppimisympäristöjen keskeisiä piirteitä. Mannisen mukaan verkko tarjoaa aikuisopiskelijalle monia mahdollisuuksia, kuten opiskelijan elämäntilanteen ja kokemuksen sekä asiantuntemuksen joustavan hyödyntämisen. Verkkopohjaisten oppimisratkaisuiden potentiaalista huolimatta harvalla on kuitenkaan tarvittavaa osaamista tai mahdollisuuksia oppimisympäristöjen maksimaaliseen hyödyntämiseen. Nevgin \& Tirrin mukaan verkko-opiskelua on rajoittanut niin opiskelijoiden tekniset, taloudelliset kuin opiskeltavaan aiheeseen liittyvät lähtökohdat. Vaikeuksia voidaan kuitenkin ainakin osittain ennaltaehkäistä opintojen suunnitteluvaiheessa huolellisella lähtötaso- kartoituksella ja heterogeenisen opiskelijaryhmän valinnalla.

\section{Oppimisen ohjauksen}

kriteereiden määrittäminen on toinen kirjan kantavista teemoista. Kiviniemen mukaan verkko-opiskelu on perusluonteeltaan itsenäistä, mutta opiskelun onnistuminen vaatii tehokkaan, autonomisuutta tukevan ohjausjärjestelmän. Keskeisimpiä tekijöitä ohjausjärjestelmässä ovat verkkomateriaalit, oppimistehtävät, yhteisöllinen oppiminen ja tutorointi. Koivisto \& Ilomäki syventävät oppimisen ohjausanalyysiä arvioimalla ammatillisten oppilaitosten opettajien verkko-opetusteknologian käyttöön liittyviä kykyjä. Teknologian käyttö on luonnollisesti lisääntynyt ja kehittynytkin opettajien keskuudessa, mutta käytön lisääntyminen on ollut melko hidasta. Keskeisin syy hitauteen on ollut teknologian käytön opastus, joka on keskittynyt lähes yksinomaan tekniseen tukeen pedagogisten näkökohtien sijasta.

\section{Kolmantena kirjan pää-} teemana on yhteisöllisyyden toteutuminen verkko-opiskelussa. Lehdon \& Tervan tutkimustulosten mukaan yhteisöllisyys on verkko-opiskelussa juuri nyt hyvin matalaa tai se puuttuu kokonaan. Tulevaisuus näyttää kuitenkin paremmalta. Argumentointinsa tukena Lehto \& Terva käyttävät viestintäalan opiskelijoita, joiden keskuudessa verkkoopiskelun yhteisöllisyys to- 
teutuu jo nyt lähes ideaalisella tavalla. Lehto \& Terva uskovat myös muiden opiskelijaryhmien saavuttavan vähitellen viestintäopiskelijoiden kaltaisia tuloksia. Marttunen \& Laurinen tutkivat tarkemmin yhteisöllisen ajattelun kehittymistä verkko-opiskelussa vertaamalla sähköpostitse käytävää pienryhmäkeskustelua vastaavaan suulliseen keskusteluun. Hieman yllättäen yhteisöllisyys näyttää toteutuvan sähköpostikeskustelussa selkeämmin kuin suullisessa keskustelussa. Keskeiseksi tulosta selittäväksi tekijäksi Marttunen \& Laurinen nostavat sähköpostin demokraattisuuden. Sähköpostikeskustelussa opiskelija joutuu suullista keskustelua helpommin kohtaamaan ristiriitatilanteet, eikä sähköpostin välityksellä ole helppoa dominoida keskustelua. Verkko-opiskelun yhteisöllisyyden toteutumiseen voidaan suhtautua vieläkin luottavaisemmin. Mäyrän mukaan verkkoopiskelu hajauttaa vielä nykyäänkin voimissaan olevan opettajasidonnaisen ja sopeuttavan opetuskulttuurin vuorovaikutteiseksi, tietoa tuottavaksi oppimiskulttuuriksi.

\section{Neljäntenä kirjan pää-}

teemana on verkko-oppimisen soveltaminen spesifeihin toimintaympäristöihin. Martikainen \& Florath katsovat verkkopalveluiden kehittymisen kohottaneen uudelleen YLE:n merkitystä oppimisen tukijana. Erityisen suuri rooli YLE:1lä on verkko-oppimisen tasa-arvoisuuden edistämisessä, sillä YLE voi toiminnallaan huolehtia opetustarjonnan edullisuudesta, saatavuudesta ja helppokäyttöisyydestä sekä ammatillisen ja yleissivistävän opetuksen järjestämisestä. Vapaassa sivistystyössä siirtyminen verkkoteknologiaan ei Sarjan mukaan ole tapahtunut yhtä luontevasti kuin YLE:ssä. Suomessa vapaan sivistystyön vieminen nettiin on toteutunut hyvin hitaasti ja pienillä resursseilla. Myös yliopistoilla on ollut ongelmia. Pohjosen arvion mukaan yliopistojen verkkopohjaisiin oppimisympäristöihin liittyvä kehitystyö ei ole ollut strategista, vaan ainoastaan yksittäisten projektien varassa. Todellisen verkko-oppimiskulttuurin luominen edellyttääkin syvällistä yliopistojen rakenteiden ja normien uudelleenmuokkausta.

\section{Kirjan viides ja kenties} merkittävin teema on kriittisyys, joka toteutuu ansiokkaasti kirjan kaikissa artikkeleissa. Erityisesti Suorannan \& Tomperin kirjan lopussa esittämä pohdinta herättää paljon kysymyksiä. Suorannan \& Tomperin artikkelissa verkkoteknologiaa ei tarkastella enää oppimisen tai opettamisen sujuvuuden, vaan yhteiskunnan näkökulmasta. Vastinpareina ovat aikuiskasvatus ja teknokapitalismi. Suorannan \& Tomperin keskeisimpänä argumenttina on, että aikuiskasvatus ei saa tuottaa yhteiskunnan valtanormina olevaan teknologian ihannointiin sopeutuvia osaajia, vaan kriittisiä, sääntöjä ja käytäntöjä uudistavia aktivisteja.

\section{Kirja onnistuu}

vastaamaan hyvin sille asetettuihin tavoitteisiin. Lukijalle jää selkeä ja kattava kuva verkko-oppimisen nykytilasta ja tulevaisuuden kehitysnäkymistä. Myös kriittisyysnäkökulma toteutuu kirjassa niin vahvasti, että sekä verkkooppimisen puolestapuhujat että vastustajat joutuvat välittömän lukukokemuksen jälkeen pohtimaan verkkoteknologian oikeutusta aikuiskoulutuksessa.

\section{Verkko-oppimisen}

vastustajat saavat kirjasta paljon tarttumapinta-alaa. Lähes kaikkien kirjoittajien mukaan verkkopohjaisten oppimisympäristöjen kehittäminen on pedagogisesta näkökulmasta tarkasteltuna vielä lähes lasten kengissä. Monilla käyttäjäryhmillä on myös vaikeuksia oppimisympäristöjen teknisessä hallinnassa, vaikka juuri tekniseen tukeen on panostettu huomattavasti pedagogista ohjausta enemmän. Kaikilla opiskelijaryhmillä ei myöskään ole taloudellisia mahdollisuuksia osallistua verkkoopetukseen. Lisäksi verkkoopetusteknologian pelätään vääristävän ihmisen ja koneen välistä suhdetta inhimillistämällä tietokonetta ja konemaistamalla opiskelijaa.

\section{Kokonaisuutena kirja} edustaa kuitenkin verkkomyönteistä näkökulmaa. Vaikka kirjoittajat myöntävät verkkopohjaisissa oppimisympäristöissä olevan vielä suuria puutteita, tulevaisuuteen suhtaudutaan valoisasti. Tästä osoituksena ovat onnistuneet yksittäiset opetus- ja oppimisesimerkit. Ratkaisevinta näiden esimerkkien laajemmalle leviämisen kannalta on, kyetäänkö verkkopohjaisten oppimisympäristöjen teknisten ominaisuuksien ihannoimisesta siirtymään jatkossa inhimillisen vuorovaikutuksen ja yhteisöllisyyden korostamiseen.

Ville Pietiläinen 